\title{
Performance and egg quality parameters of laying hens submitted to different rearing densities
}

\section{Desempenho e qualidade de ovos de poedeiras leves submetidas à diferentes densidades populacionais}

\author{
Lidiane Silva do Espírito Santo ${ }^{1 *}$; Gerusa da Silva Salles Correa²; \\ Flávio Medeiros Vieites ${ }^{3}$; Alessandra Romani ${ }^{1}$; João Marcos Novais Tavares ${ }^{1}$; \\ Guilherme Moreira de Melo Silva ${ }^{4}$, Cleber Franklin Santos de Oliveira ${ }^{5}$
}

\begin{abstract}
This study aimed to evaluate the effect of different rearing densities during brooding ( 0 to 2 weeks) and growth (3 to 15 weeks) on performance and egg quality of laying hens (Hy-line W-36) during production phase (18 to 42 weeks). In the brooding phase, a total of 3250 day-old chicks were allocated in wire cages, distributed in a completely randomized design composed of 5 treatments $(63.57 ; 66.38$; $69.44 ; 72.80$ and $76.50 \mathrm{~cm}^{2} /$ bird) with 10 replications each. At the beginning of the growth phase, floor space in each treatment was increased. Therefore, a total of 750 birds were selected from the original treatments, which represented 237.57, 265.52, 300.92, 347.22, and $410.35 \mathrm{~cm}^{2} / \mathrm{bird}$. At the end of the growing phase, 390 pullets were transferred to production facilities and distributed, according to their original treatment, in conventional cages with $430.76 \mathrm{~cm}^{2} /$ bird (13 birds/cage). For this phase, only 6 replications per treatment were adopted. Experimental data were subjected to analysis of variance and, in the case of significant differences, means were analyzed using polynomial regression test. Body weight, weight gain and uniformity were compared during the brooding and growth phases. First-egg weight, age at first egg, age at 50\% daily production, weights of egg, albumen, yolk and shell, egg mass, yolk diameter, yolk height, yolk index, albumen height, percentages of shell, albumen and yolk, shell thickness, Haugh unit, and egg specific gravity were analyzed during the production stage. In conclusion, raising pullets on $63.57 \mathrm{~cm}^{2} /$ bird (71 birds/cage) does not affect chicks' performance during the brooding phase. However, for the growth phase, the recommendation is to provide $410.35 \mathrm{~cm}^{2} / \mathrm{bird}$, which corresponded to $11 \mathrm{birds} / \mathrm{cage}$ in this research. For the production period, the recommendation is to utilize pullets raised on $265.52 \mathrm{~cm}^{2} /$ bird, which corresponded to $17 \mathrm{birds} / \mathrm{cage}$ on this research.
\end{abstract}

Key words: Performance. Uniformity. Weight gain.

\section{Resumo}

O objetivo foi avaliar diferentes densidades populacionais nas fases de cria, recria sobre a produção de poedeiras leves comerciais (linhagem Hy-line W-36). O experimento foi dividido em três fases: cria ( 0 a

\footnotetext{
${ }^{1}$ Discentes, Curso de Mestrado do Programa de Pós-Graduação em Ciência Animal, Universidade Federal de Mato Grosso, UFMT, Cuiabá, MT, Brasil. E-mail: lidianezootecnia@hotmail.com; alessandraromani@hotmail.com; tavares.jmn@gmail.com

2 Prof ${ }^{a}$ Dra $^{a}$, UFMT, Programa de Pós-Graduação em Ciência Animal, Cuiabá, MT, Brasil. E-mail: gerusacorrea@hotmail.com

${ }^{3}$ Prof. Dr., Universidade Federal de Juiz de Fora, UFJF, Faculdade de Medicina Veterinária, Juiz de Fora, MG, Brasil. E-mail: fmvieites@yahoo.com

${ }^{4}$ Gerente de Avicultura, Granja Mantiqueira, Primavera do Leste, MT, Brasil. E-mail: guilhermemoreira@granjamantiqueira.com. br

5 Pós Dr., Programa de Pós-Graduação em Ciência Animal, UFMT, Cuiabá, MT, Brasil. E-mail: c_f_s_o@hotmail.com

* Author for correspondence
} 
duas semanas), recria (três a 15 semanas) e produção (18 a 42 semanas de idade). Em ambas as fases foi utilizado o delineamento inteiramente casualizado. Na fase de cria foram utilizadas 3250 pintainhas, de um dia de idade que foram distribuídas em cinco tratamentos 63,$57 ; 66,38 ; 69,44 ; 72,80$ e 76,50 $\mathrm{cm}^{2} /$ ave com dez repetições cada. Para a fase de recria foram selecionadas 750 aves provenientes dos tratamentos utilizados na fase de cria, e redistribuídas em cinco tratamentos $(237,57 ; 265,52 ; 300,92 ; 347,22$ e $410,35 \mathrm{~cm}^{2} /$ ave) com dez repetições por tratamento. Na fase de produção as aves foram alojadas com a mesma densidade para isso foram utilizadas 455 poedeiras advindas de cada tratamento utilizadas nas fases de cria e recria e foram distribuídas em cinco tratamentos com a mesma densidade de $430,76 \mathrm{~cm}^{2} /$ ave que corresponde a 13 aves/gaiola com seis repetições. As variáveis analisadas para as fases de cria e recria foram: peso médio, ganho de peso e uniformidade e na fase de produção as variáveis foram: idade e peso do ovo a primeira postura e a idade aos $50 \%$ de produção, peso do ovo, peso do albúmen, gema e casca, massa do ovo, diâmetro e índice de gema, altura de gema e albúmen, porcentagens de casca, albúmen e gema, espessura da casca, unidade Haugh e gravidade específica. Os dados experimentais foram submetidos à análise de variância, e em caso de diferença, as médias foram analisadas utilizando testes de regressão polinomial. Na fase de cria é possível criar as aves na densidade de $63,57 \mathrm{~cm} 2 /$ ave ou 71 aves/gaiola sem comprometer o desempenho das aves. Para a fase de recria recomenda-se uma densidade de 410,35 $\mathrm{cm}^{2} /$ ave que corresponde a 11 aves/gaiola. Na fase de produção, recomenda-se as aves provenientes da densidade $265,52 \mathrm{~cm}^{2} /$ ave que corresponde a 18 aves/gaiola.

Palavras-chave: Ganho de peso. Produção. Uniformidade.

\section{Introduction}

The high technological standards observed in modern egg-production systems aim to reduce production costs by increasing the productivity of facilities. In this sense, both bird performance and physical space exploration could affect profitability. Increasing the rearing density of birds is a tendency in commercial egg farms, particularly for young pullets. However, as genetic selection has been developing increasingly lighter and more productive birds, new studies are necessary for a precise recommendation on the ideal rearing density for modern pullets and hens (PAVAN et al., 2005).

Although the reduction of floor space per bird in conventional cages maximizes profitability, this practice could negatively affect the animal welfare status (ROCHA et al., 2008). Despite the importance of this issue for egg production, few published studies have evaluated the impact of rearing density of pullets on their later performance and egg quality.

The objective of this research was to evaluate the impact of different rearing densities on brooding and growth on later hen performance and egg quality parameters.

\section{Materials and Methods}

One experiment was conducted in a commercial egg farm located in the city of Primavera do Leste, Mato Grosso, Brazil, between October 2014 and August 2015, with Hy-Line W36 birds. For the initial period, day-old chicks were allocated in conventional wire cages $(74 \mathrm{~cm}$ width $\mathrm{x} 61 \mathrm{~cm}$ length $\mathrm{x} 42 \mathrm{~cm}$ height) equipped with nipple drinkers and automatic linear feeders, placed inside a conventional open-sided house. Feed and water were provided ad libitum throughout the entire experimental period. During the brooding phase, house temperature was maintained at thermoneutrality by diesel heaters. Lighting program was set to $24 \mathrm{~h}$ brightness for the first 7 days (natural plus artificial). After that, artificial light period decreased by one hour per week until week 10, when the birds started to receive only natural day light.

Under these conditions, a total of 3250 dayold chicks $(38 \pm 0.053 \mathrm{~g})$ were distributed in a completely randomized design composed of 5 treatments $(63.57 ; 66.38 ; 69.44 ; 72.80$; and 76.50 $\mathrm{cm}^{2} /$ bird) with 10 replications each. In order to achieve these densities, the number of chicks raised 
per cage was $71,68,65,62$, and 59 , respectively. All the birds were kept in this condition until day 14 , which was adopted as the end of the brooding phase. At the beginning of the day 15 , floor space per bird was increased in each treatment by reducing the number of chicks per cage. Thus, the cages of each treatment began to accommodate 19, $17,15,13$, or 11 birds, respectively, which represent 237.57; 265.52; 300.92; 347.22; and $410.35 \mathrm{~cm}^{2} /$ bird. Animals were kept in this condition until week 15 , adopted as the end of the growth phase.

At the end of brooding and growth phases, body weight, weight gain and uniformity were evaluated in each cage. For that, birds were individually weighed using a digital scale with an accuracy of $0.1 \mathrm{~g}$. Uniformity was calculated as the percentage of birds whose weights stayed between the cage's average weight $\pm 10 \%$. In the case of mortality, dead birds were replaced by leg-ringed birds raised specifically for this reason. These birds were not taken for body weight, weight gain or uniformity evaluations.

In week 16, birds were transferred to production facilities, which were composed of conventional wire cages $(70 \mathrm{~cm}$ width $\mathrm{x} 80 \mathrm{~cm}$ length $\mathrm{x} 40 \mathrm{~cm}$ height) equipped with nipple drinkers and automatic linear feeders, placed inside a conventional opensided house. Water and feed were provided ad libitum and the light program was set to $17 \mathrm{~h}$ of brightness per day (natural plus artificial).

In order to evaluate the residual effect of the rearing densities during brooding and growth on the production stage, a total of 390 hens were distributed, according to their original treatments, in a completely randomized designed composed of 5 treatments with 6 replications of 13 birds each. Thus, floor space available for the birds in this phase was the same for all treatments $\left(430.76 \mathrm{~cm}^{2} /\right.$ bird $)$. In order to replace the dead birds during the trial, a further 65 birds (13 from each original treatment) were placed in 5 different cages for constituting the replacement birds. In addition, to maintain the density of 13 birds per cage in the replacement cages, aleatory leg-ringed birds replaced the ones utilized in the trial.

The first 10 weeks in the production facilities (16 to 26 weeks) was adopted as the time required for the hens to stabilize egg production. During this time, first-egg weight, age at the first egg, and age at $50 \%$ daily egg production were recorded. After this period, between 27 and 42 weeks, eggs were collected twice a day ( 9 am and $2 \mathrm{pm}$ ) to count egg production and defective eggs (broken, cracked, fissured and dirty). Moreover, at the end of each 28-day period, all the intact eggs of the day were weighed, analyzed for specific gravity, and 9 eggs per replication were taken for internal and external quality analysis (weighs of albumen, yolk and shell; yolk diameter, height and index; albumen height; Haugh unit; percentages of shell, albumen and yolk; and shell thickness).

To determine egg-specific gravity, 9 salt solutions with different densities (varying by 0.005 , from 1.060 to $1.100 \mathrm{~g} / \mathrm{cm}^{3}$ ) were prepared with the aid of an oil hydrometer (Incoterm-OM- $5565^{\circledR}$ ) and arranged in ascending order. After being weighed, eggs were sequentially immersed in the solutions, and the density of the solution in which they first floated was considered to be the egg's specific gravity, as described by Hamilton (1982).

To determine egg internal and external quality, eggs were cracked on a flat surface. With the aid of a digital caliper (Mitutoyo ${ }^{\circledR}, 0.001 \mathrm{~mm}$ accuracy), yolk diameter and height, and albumen height was measured. Yolk index was determined by the following formula: $Y I=$ yolk height $(\mathrm{mm}) /$ yolk diameter $(\mathrm{mm})$, as described by Sharp and Powell (1930). Yolk was then isolated from albumen and weighed. The Haugh unit was calculated by the following formula: $H U=100 \log [h+7.57$ $\left.1.7 w^{0.37}\right]$, where " $h$ " corresponds to albumen height and " $w$ " to egg weight (NESHEIM et al., 1979). Egg mass was obtained by multiplication of the average egg weight by the egg production. 
Shells were washed and set to dry at room temperature. After $24 \mathrm{~h}$, the shells were weighed and their thickness (including membranes) was measured with a digital caliper in three different regions. The mean value of the three measurements was considered a single observation. The albumen weight was calculated as the whole-egg weight minus the shell and yolk weights. The weights of the egg components were transformed to percentages of the whole egg for analysis and presentation.

The experimental data were submitted to analysis of variance and, when significant differences were detected, means were analyzed by polynomial regression test.

\section{Results and Discussion}

No effect of treatments was observed on performance parameters during the brooding phase (Table 1), indicating that high densities could be adopted in this stage without any impact on body weight, weight gain and flock uniformity. These results are in agreement with previous trials, which also described no effect of rearing density on weight gain (PATTERSON; SIEGEL, 1998), body weight and flock uniformity (PAVAN et al., 2005) of pullets during the first weeks of life. On the contrary, Rech et al. (2010) concluded that the reduction on floor space provided for birds significantly impairs weight gain. Differences in the values of floor space analyzed in each work could explain these discrepant results. Pavan et al. (2005) stated that genetic selection increased the ability of the modern laying hen to adapt to reduced spaces, which could explain the lack of an effect of treatments observed here. Moreover, the 14-day brooding period might have been too short to detect any influence of the treatments on body development.

Table 1. Body weight, weight gain, and uniformity of pullets submitted to different rearing densities during the brooding phase.

\begin{tabular}{cccc}
\hline Rearing density $\left(\mathrm{cm}^{2} /\right.$ bird $)$ - birds per cage & Body weight $(\mathrm{g})$ & Weight gain $(\mathrm{g})$ & Uniformity $(\%)$ \\
\hline $63.57-71$ & 94.93 & 56.93 & 89.63 \\
$66.38-68$ & 93.43 & 55.43 & 89.42 \\
$69.44-65$ & 97.82 & 59.82 & 89.34 \\
$72.80-62$ & 94.93 & 56.93 & 89.19 \\
$76.50-59$ & 98.10 & 60.10 & 89.63 \\
\hline Mean & 95.84 & 57.84 & 89.44 \\
Effect & $\mathrm{NS}$ & $\mathrm{NS}$ & $\mathrm{NS}$ \\
$p$ value & 0.1460 & 0.2303 & 0.9677 \\
SEM & 0.737 & 0.411 & 0.081 \\
\hline
\end{tabular}

$\mathrm{NS}=$ not significant; $\mathrm{SEM}=$ standard error of the mean.

The influence of high rearing densities on flock aggressiveness and cannibalism has been previously demonstrated (MASHALY et al., 1984; CRAIG et al., 1986). However, no difference in birds' behavior between treatments was observed in this research. Average mortality was lower than
$2 \%$, which is accepted as normal for pullets during the evaluated period (VAN HIERDEN et al., 2002). These findings probably show that physiological responses related to stress were kept at basal levels and thus the birds' requirements of welfare were assured in all treatments. 
During the growth phase, body weight and weight gain was reduced linearly according to the increase in rearing density (Table 2, Figures 1 and 2). According to Carey and Kuo (1995), high rearing densities could affect hen performance by increasing the competition for space. The reduction in floor space per bird restricts body movement and reduces access to feeders and drinkers, which decreases feed and water consumption and could impair weight gain, egg production, egg weight, and feed efficiency, whilst also increasing the incidence of skeletal disorders and mortality (WEBSTER, 2004; RIOS et al., 2009). Otherwise, Garcia (2003) studied the effect of rearing density on caged laying hens and did not find an effect of the treatments on weight gain at 16 weeks. Moreover, comparing birds raised on $225,250,281$, and $321.4 \mathrm{~cm}^{2} /$ bird between 10 and 16 weeks, Brito et al. (2004) did not detect an effect of treatments on flock uniformity, even though the weight gain decreased as the rearing density increased.

Table 2. Body weight, weight gain, and uniformity of pullets submitted to different rearing densities during the growth phase.

\begin{tabular}{cccc}
\hline Rearing density $\left(\mathrm{cm}^{2} /\right.$ bird $)$ - birds per cage & Body weight $(\mathrm{g})$ & Weight gain $(\mathrm{g})$ & Uniformity $(\%)$ \\
\hline $237.57-19$ & 997 & 888 & 93.86 \\
$265.52-17$ & 996 & 886 & 93.40 \\
$300.92-15$ & 1004 & 894 & 92.94 \\
$347.22-13$ & 1008 & 898 & 91.09 \\
$410.35-11$ & 1034 & 924 & 93.69 \\
\hline Mean & 1010 & 898 & 93.00 \\
Effect & $\mathrm{L}^{*}$ & $\mathrm{~L}^{*}$ & $\mathrm{NS}$ \\
$p$ value & 0.0039 & 0.0041 & 0.6378 \\
SEM & 0.175 & 0.176 & 0.001 \\
\hline
\end{tabular}

$\mathrm{NS}=$ not significant; SEM = standard error of the mean.

Figure 1. Body weight of pullets submitted to different rearing densities during the growth phase.

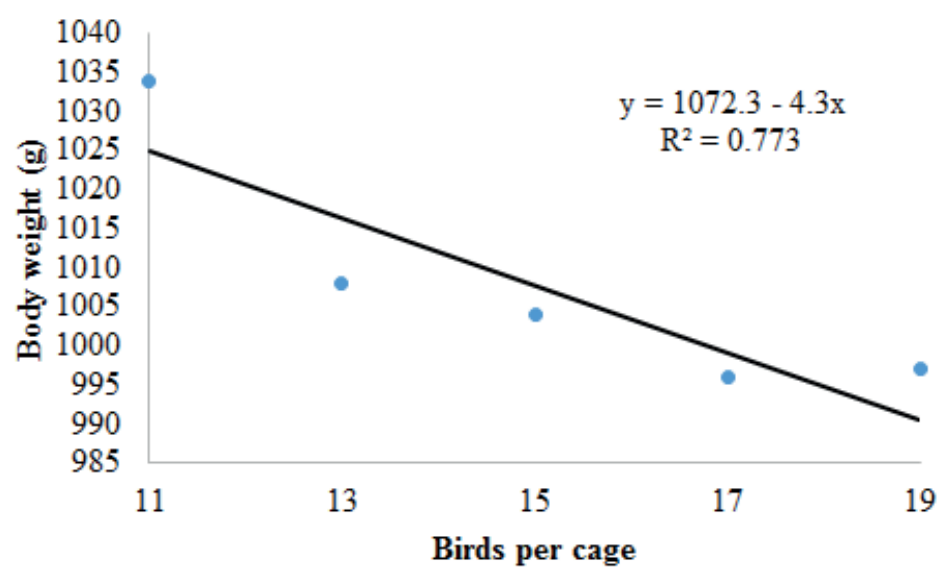


Figure 2. Weight gain of pullets submitted to different rearing densities during the growth phase.

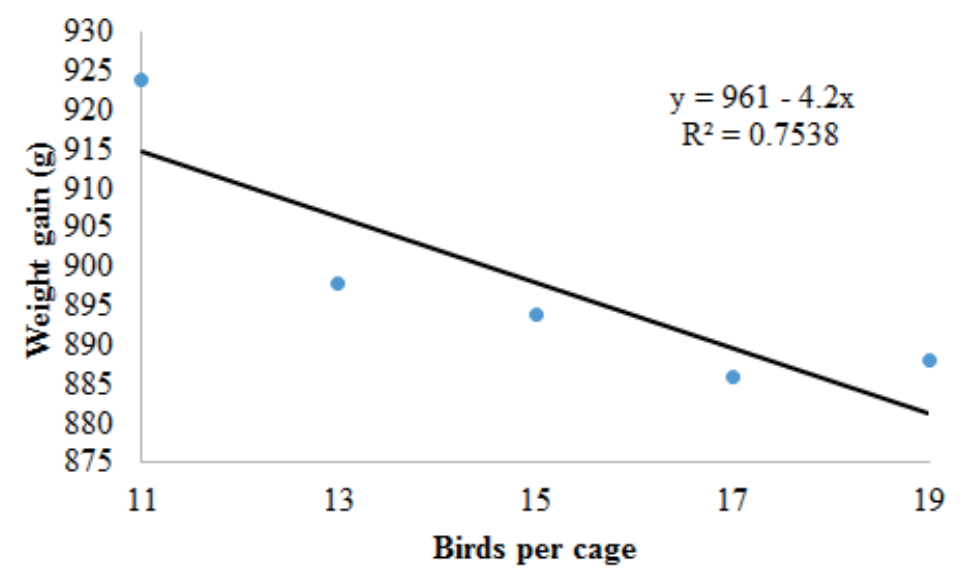

Pavan et al. (2005) described no difference in weight gain of pullets raised in three different densities (500, 416.67 and $357.15 \mathrm{~cm}^{2} /$ bird) between 6 and 16 weeks of age. Similar results were described by Anderson and Adams (1992) for 18-week-old Leghorn pullets raised in 221, 249, 277 and $304 \mathrm{~cm}^{2} /$ bird. However, when another group of pullets was submitted to $193 \mathrm{~cm}^{2} / \mathrm{bird}$, the same authors observed a reduction in body weight. These results prove that the reduction in floor space provided for birds may impair weight gain, particularly during the last weeks of growth when the rate of growth is markedly high. Despite of that, no effect of treatments was detected on pullets' uniformity (Table 2), indicating that all the birds in the cage were similarly affected by the treatment.

According to the results obtained for the growth phase, pullets raised with more floor space (410.35 $\mathrm{cm}^{2} /$ bird) show better performance; however, the decision to establish the ideal rearing density in commercial farms has to consider the economic viability of its implementation. In this way, Patterson and Siegel (1998) suggested the use of $284 \mathrm{~cm}^{2} /$ bird during the growth stage as a way to balance raising conditions and performance.
No effect of treatments was detected for the analyzed variables during the beginning of production stage (Table 3). First-egg mean weight was $42.8 \mathrm{~g}$, mean age at the first egg was 136 days, and mean age at $50 \%$ daily egg production was 149 days. These values are very similar to those described in the management guides, except for the first-egg mean weight, which has an expected value of $44.6 \mathrm{~g}$. Anderson and Adams (1992) did not find an effect of rearing density on the age of sexual maturation in white Leghorn pullets too. However, Carey (1987) described a significant reduction in the age of sexual maturation of pullets raised on 222 $\mathrm{cm}^{2}$ when compared to others raised on 259 or 311 $\mathrm{cm}^{2}$.

The impact of the treatments on performance during the growth phase did not influence the performance parameters during the production stage (Table 4). Similar results were described by Meunier-Salaün et al. (1984) when analyzing the impact of pullets' raising conditions on later productive performance of the flock. The authors concluded that some interventions in raising conditions during the growth phase do not cause permanent effects on birds and so do not affect performance or behavioral patterns during adulthood. 
Table 3. First-egg weight, age at the first egg, and age at $50 \%$ daily egg production of laying hens submitted to different rearing densities during the growth phase.

\begin{tabular}{ccccc}
\hline $\begin{array}{c}\text { Rearing density at growth } \\
\left(\mathrm{cm}^{2} / \text { bird }\right) \text { - birds per cage }\end{array}$ & $\begin{array}{c}\text { Rearing density at production } \\
\left(\mathrm{cm}^{2} / \text { bird }\right) \text { - birds per cage }\end{array}$ & $\begin{array}{c}\text { First-egg } \\
\text { weight }(\mathrm{g})\end{array}$ & $\begin{array}{c}\text { Age at the first } \\
\text { egg (days) }\end{array}$ & $\begin{array}{c}\text { Age at 50\% daily egg } \\
\text { production (days) }\end{array}$ \\
\hline $237.57-19$ & $430.76-13$ & 42.50 & 137 & 151 \\
$265.52-17$ & $430.76-13$ & 42.50 & 136 & 148 \\
$300.92-15$ & $430.76-13$ & 44.00 & 138 & 149 \\
$347.22-13$ & $430.76-13$ & 43.00 & 133 & 148 \\
$410.35-11$ & $430.76-13$ & 42.00 & 135 & 149 \\
\hline Mean & - & 42.80 & 136 & 149 \\
Effect & - & $\mathrm{NS}$ & $\mathrm{NS}$ & $\mathrm{NS}$ \\
$p$ value & - & 0.9204 & 0.1044 & 0.696 \\
SEM & - & 0.505 & 0.320 & 0.391 \\
\hline
\end{tabular}

NS $=$ not significant; $\mathrm{SEM}=$ standard error of the mean.

Table 4. Egg production, egg mass, and defective eggs of laying hens (27 to 42 weeks) submitted to different rearing densities during the growth phase.

\begin{tabular}{ccccc}
\hline $\begin{array}{c}\text { Rearing density at growth } \\
\left(\mathrm{cm}^{2} / \text { bird }\right) \text { - birds per cage }\end{array}$ & $\begin{array}{c}\text { Rearing density at production } \\
\left(\mathrm{cm}^{2} / \text { bird }\right) \text { - birds per cage }\end{array}$ & $\begin{array}{c}\text { Egg production } \\
(\%)\end{array}$ & $\begin{array}{c}\text { Egg mass } \\
(\mathrm{g})\end{array}$ & $\begin{array}{c}\text { Deffective eggs } \\
(\%)\end{array}$ \\
\hline $237.57-19$ & $430.76-13$ & 89.26 & 53.21 & 16.21 \\
$265.52-17$ & $430.76-13$ & 87.72 & 51.52 & 15.02 \\
$300.92-15$ & $430.76-13$ & 88.63 & 53.02 & 15.22 \\
$347.22-13$ & $430.76-13$ & 89.13 & 52.34 & 14.94 \\
$410.35-11$ & $430.76-13$ & 86.40 & 51.78 & 16.97 \\
\hline Mean & - & 88.22 & 52.37 & 15.67 \\
Effect & - & $\mathrm{NS}$ & $\mathrm{NS}$ & $\mathrm{NS}$ \\
$p$ value & - & 0.1800 & 0.1075 & 0.5763 \\
SEM & - & 0.077 & 0.052 & 0.213 \\
\hline
\end{tabular}

NS = not significant; $\mathrm{SEM}=$ standard error of the mean .

Many authors utilize the analysis of productive parameters and egg quality to measure the impact of the raising environment on animal welfare (ALVES et al., 2007). No effect of treatment was detected in this research for the variables egg mass (Table 4) and egg weight (Table 5). Similar results were described by Pavan et al. (2005) in a study conducted to compare the effects of two different raising densities (357 and $500 \mathrm{~cm}^{2} /$ bird) during the growth phase on later performance of the hens. Anderson et al. (2004) described a reduction in egg mass in hens submitted to a higher raising density during the growth phase (361 versus $482 \mathrm{~cm}^{2} /$ bird). Menezes et al. (2009) described a tendency towards egg mass increase in hens raised at $625 \mathrm{~cm}^{2} /$ bird when compared to hens raised at $357.14 \mathrm{~cm}^{2} /$ bird. 


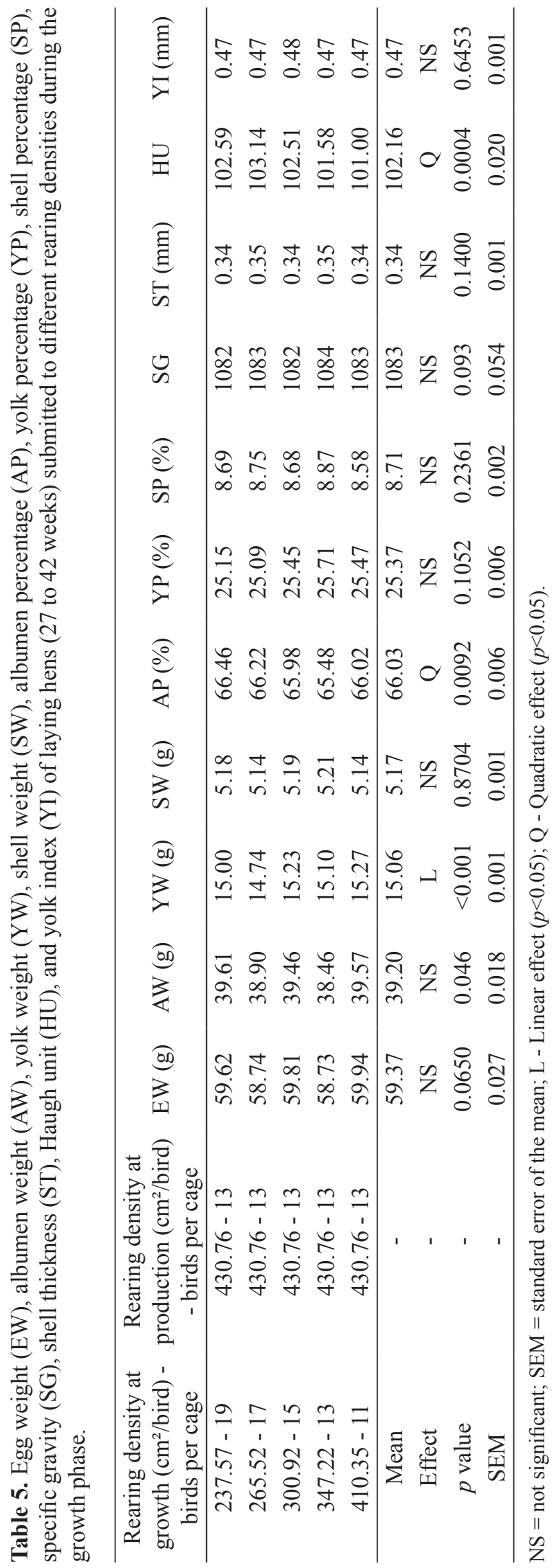


There was no effect of treatment on the percentage of defective eggs. Frequently, a higher incidence of broken, cracked, and dirty eggs is described at high raising densities because this favors the contact between hens and eggs inside the cage (GARCIA et al., 2015). In fact, Carey and Kuo (1995) observed a reduction in the incidence of cracked eggs when the number of hens raised in the cage was decreased. However, this was not the case in this research, since the raising density during the production phase was the same for all the treatments. Other studies also described no effect of raising density on the incidence of egg defects (CARVALHO et al., 2005; PAVAN et al., 2005; MENEZES et al., 2009). Albumen weight, shell weight, percentage of yolk, percentage of shell, specific gravity, shell thickness, and yolk index were not affected by treatments (Table 5). On the contrary, yolk weight responded linearly to the increase in raising density.

Egg-specific gravity could be considered an estimate of the amount of shell deposited in the egg and its value is frequently associated to the thickness and percentage of shell. Our results demonstrated that egg shells were in a very good condition, since according to SCOTT (1995), values above 1.080 indicate good shell quality. Egg-specific gravity decreases according to the reduction in the thickness of the shell, which leads to a higher susceptibility to cracking. Thus, shell thickness measurement is another way to estimate the shell quality. None of these parameters were affected by treatments in this research.

Quadratic effect of raising density was detected for the Haugh unit (Table 5, Figure 3) and its highest value was observed in hens originated from the $265.52 \mathrm{~cm}^{2} /$ bird treatment. The Haugh unit has been adopted mainly as an indicator of albumen quality, i.e., the higher its value, the better the albumen quality. In this research, all of the observed values could be classified as good (higher than 100). According to the USDA (2000), eggs may be classified by the Haugh unit in AA (72 to 100), A (60 to 71$)$, B (30 to 59$)$ and $\mathrm{C}(0$ to 29$)$. The age of the hen affects the value of the Haugh unit, so it is common to find higher values of Hough unit in younger flocks.

Figure 3. Haugh unit from eggs of laying hens (27 to 42 weeks) submitted to different rearing densities during the growth phase.

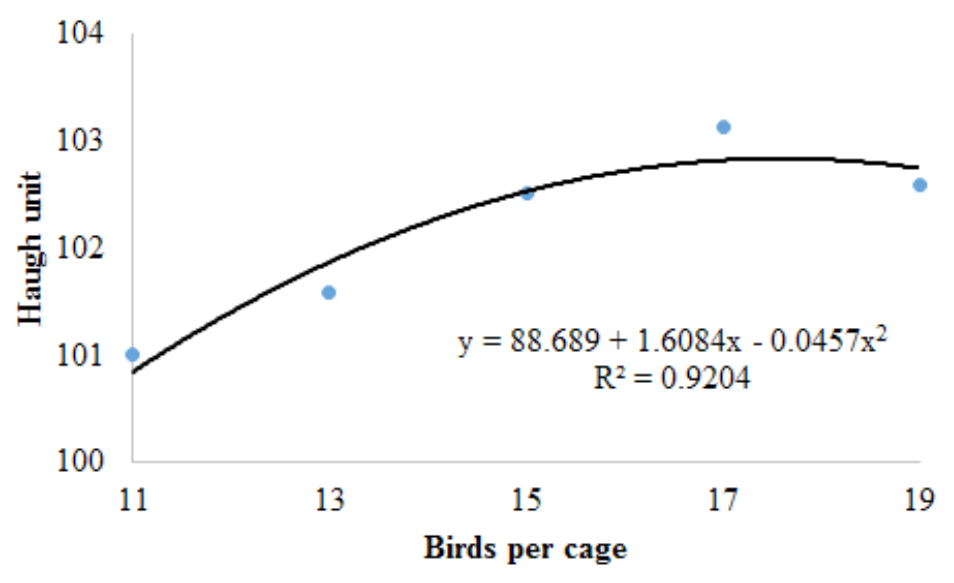

The standard range for yolk index on fresh eggs is between 0.30 and 0.45 . According to Menezes (2011), lower values are indicative of fragility in the yolk structure. This condition did not occur in the present research, since the observed values were higher than 0.45 in all the treatments. Pavan et al. 
(2005) and Garcia et al. (2015) described similar results when analyzing the effect of different rearing densities on egg quality parameters.

\section{Conclusions}

Raising pullets at $63.57 \mathrm{~cm}^{2} /$ bird or 71 birds/ cage does not affect chicks' performance during the brooding phase. However, for the growth stage, the recommendation is to provide 410.35 $\mathrm{cm}^{2} /$ bird, which corresponded to 11 birds/cage on this research. For the production period, the recommendation is to utilize pullets raised at $265.52 \mathrm{~cm}^{2} / \mathrm{bird}$, which corresponded to $17 \mathrm{birds} /$ cage on this research.

\section{References}

ALVES, S. P.; SILVA, I. J. O.; PIEDADE, S. M. Avaliação do bem-estar de aves poedeiras comerciais: efeitos do sistema de criação e do ambiente bioclimático sobre o desempenho das aves e a qualidade de ovos. Revista Brasileira de Zootecnia, Viçosa, MG, v. 36, n. 5, p. 1388-1394, 2007.

ANDERSON, K. E.; ADAMS, A. W. Effects of rearing density and feeder and waterer spaces on the productivity and fearful behavior of layers. Poultry Science, Champaign, v. 71, n. 1, p. 53-58, 1992.

ANDERSON, K. E.; DAVIS, G. S.; JENKINS, P. K.; CARROLL, A. S. Effects of bird age, density, and molt on behavioral profiles of two commercial layer strains in cages. Poultry Science, Champaign, v. 83, n. 1, p. 15-23, 2004.

BRITO, J. A. G.; SILVA, J. M. A.; CARVALHO, J. C. C.; BERTECHINI, A. G.; KANJI KATO, R. Influência de diferentes densidades de criação sobre o desempenho e uniformidade de frangas leves na recria. In: CONGRESSO DOS PÓS-GRADUANDOS DA UFLA, 13., 2004, Lavras. Anais... Lavras: UFLA, 2004. p. 13.

CAREY, J. B. Effect of pullet-stocking density on performance of laying hens. Poultry Science, Champaign, v. 66, n. 8 , p. $1283-1287,1987$.

CAREY, J. B.; KUO, F. L.; ANDERSON, K. E. Effects of cage population on the productive performance of layers. Poultry Science, Champaign, v. 74, n. 4, p. 633637, 1995.
CARVALHO, J. C. C.; GERALDO, A.; BERTECHINI, A. G.; BRITO, J. A. G.; ROSA, F. C. S.; RIOS, R. L. Efeito da densidade de alojamento em gaiolas sobre o desempenho de poedeiras comerciais leves (linhagem Lohmann LSL) na fase de produção (24 a 44 semanas de idade). In: CONGRESSO DOS PÓS-GRADUANDOS DA UFLA, 14., 2005, Lavras. Anais... Lavras: UFLA, 2005. p. 14.

CRAIG, J. V.; CRAIG, J. A.; VARGAS, J. V. Corticosteroids and other indicator of hens' wellbeing in four layinghouse environments. Poultry Science, Champaign, v. 65, n. 5, p. 856-863, 1986.

GARCIA, E. A. Efeito da taxa de lotação da gaiola nas fases de cria e de recria sobre o desempenho de frangas semi pesadas na fase de recria In: CONFERÊNCIA APINCO, 2003, Campinas. Anais... Campinas: Fundação Apinco de Ciência e Tecnologia Avícola, 2003. p. 6.

GARCIA, E. R. M.; BATISTA, N. R.; NUNES, K. C.; CRUZ, F. K.; BARBOSA FILHO, J. A.; ARGUELO, N. N.; SOUZA, R. P. P.;AVILA, L. R. Desempenho produtivo e qualidade de ovos de poedeiras comerciais semipesadas criadas em diferentes densidades populacionais. Revista AGROTEC: Agropecuária Técnica, v. 36, n. 1, p. 24-29, 2015.

HAMILTON, R. M. G. Methods and factors that affect the measurement of egg shell quality. Poultry Science, Champaign, v. 61, n. 10, p. 2022-2039, 1982.

MASHALY, M. M.; WEBB, M. L.; YOUTZ, S. L.; ROUSH, W. B.; GRAVES, H. B. Changes in serum corticosterone concentration of laying hens as a response to increased population density. Poultry Science, Champaign, v. 63, n. 11, p. 2271-2274, 1984.

MENEZES, P. C. Avaliação da qualidade de ovos de poedeiras comerciais em diferentes densidades populacionais. 2011. Tese (Doutorado em Ciência Veterinária) - Universidade Federal Rural de Pernambuco, Recife.

MENEZES, P. C.; CAVALCANTI, V. F. T.; LIMA, E. R.; EVENCIO NETO, J. Aspectos produtivos e econômicos de poedeiras comerciais submetidas a diferentes densidades de alojamento. Revista Brasileira de Zootecnia, Viçosa, MG, v. 38, n. 11, p. 2224-2229, 2009.

MEUNIER-SALAÜN, M. C.; HOUN, F.; FAURE, J. M. Lack of influence of pullet rearing conditions on the hen's performance. British Poultry Science, v. 25, n. 4, p. 541-546, 1984.

NESHEIM, M. C.; AUSTIC, R. E.; CARD, L. E. Poultry production. Philadelphia: Lea \& Febiger, 1979. v. 12, $339 \mathrm{p}$. 
PATTERSON, P. H.; SIEGEL, H. S. Impact of cage density on pullet performance and blood parameters of stress. Poultry Science, v. 77, n. 1, p. 32-40, 1998.

PAVAN, A. C.; GARCIA, E. A.; MÓRI, C.; PIZZOLANTE, C. C.; PICCININ, A. Efeito da densidade na gaiola sobre o desempenho de poedeiras comerciais nas fases de cria, recria e produção. Revista Brasileira de Zootecnia, Viçosa, MG, v. 34, n. 4, p. 1320-1328, 2005.

RECH, O. A.; PINHEIRO, J. W.; FONSECA, N. A. N.; SILVA, C. A.; OBA, A. Efeito da linhagem, espaço na gaiola e nível de triptofano dietético no desempenho de poedeiras comerciais. Semina: Ciências Agrárias, Londrina, v. 31, n. 4, p. 1051-1058, 2010.

RIOS, R. L.; BERTECHINI, A. G.; CARVALHO, J. C. C.; CASTRO, S. F.; COSTA, V. A. Effect of cage density on the performance of 25- to 84-week-old laying hens. Revista Brasileira de Ciência Avícola, Campinas, v. 11, n. 4, p. 57-262, 2009.

ROCHA, J. S. R.; LARA, L. J. C.; BAIÃO, N. C. Produção e bem-estar animal aspectos éticos e técnicos da produção intensiva de aves. Ciência Veterinária nos Trópicos, v. 11, n. 1, p. 49-55, 2008.
SCOTT, M. L. Tips to improve egg shell quality. Feedstuffs, v. 67, n. 33, p. 18, 1995.

SHARP, P. F.; POWELL, C. K. Decrease in internal quality of hen's eggs during storage as by the yolk. Industrial \& Engineering Chemistry Research, v. 22, n. 3, p. 909-910, 1930.

UNITED STATES DEPARTAMENT OF AGRICULTURE - USDA. Egg-grading manual. Washington of Agriculture, 2000. 56 p. (Agriculture Marketing Service, 75).

VAN HIERDEN, Y. M.; KORTE, S. M.; RUESINK, E. W.; VAN REENEN. C. G.; ENGEL, B.; KORTBOUWS, G. A.; KOOLHAAS, J. M.; BLOKHUIS, H. J. Adrenocortical reactivity and central serotonin and dopamine turnover in young chicks from a high and low feather-pecking line of laying hens. Physiology \& Behavior, Lelystad, v. 75, n. 5, p. 653-659, 2002.

WEBSTER, A. B. Welfare implications of avian osteoporosis. Poultry Science, Champaign, v. 83, n. 2, p. 184-192, 2004. 
